\title{
A revision of two distinct species of Rhipicephalus: $R$. microplus and $R$. australis
}

\author{
Uma revisão sobre duas espécies distintas de Rhipicephalus: $R$. microplus e $R$. australis
}

\author{
Abid Ali, II Luís Fernando PariziIII Beatriz Rossetti Ferreira ${ }^{I I}$ Itabajara da Silva Vaz Junior ${ }^{\text {III, IV, v }}$
}

\section{- REVIEW -}

\section{ABSTRACT}

Rhipicephalus (Boophilus) species are monoxenous ticks with seasonal distribution in tropical and subtropical regions. For many years, Rhipicephalus microplus was considered as a single species; however, further analysis split these ticks into two distinct species. Because R. microplus and $\boldsymbol{R}$. australis share similar attributes, it is hard to discriminate these two species and explain the changes in the classification of these parasites over the past decades. The reappearance of $\boldsymbol{R}$. australis is an outcome of new research, which has afforded to better characterize these probably cryptic species. Evidence based on morphological features, the lack of conspecificity, microsatellite markers, mitochondrial $12 S$ and $16 S$ ribosomal DNA, and mitochondrial genome supports the re-classification of $\boldsymbol{R}$. microplus as different species. Therefore, populations of $\boldsymbol{R}$. microplus from Australia, Cambodia, Philippines, Indonesia, New Caledonia, Borneo, New Guinea, Tahiti and parts of Southeast Asia were recently reinstated as $\boldsymbol{R}$. australis. Moreover, a better knowledge on the speciation between these two species could pave the way to important advances in tick control strategies.

Key words: Rhipicephalus, Boophilus, microplus, australis, taxonomy.

\section{RESUMO}

As espécies pertencentes ao gênero Rhipicephalus (Boophilus) são carrapatos monoxenos de distribuição sazonal em regiões tropicais e subtropicais. Por muito anos, duas espécies de carrapatos foram consideradas como Rhipicephalus microplus. Contudo, estudos recentes reclassificaram esse carrapato em duas espécies: $\boldsymbol{R}$. microplus e R. australis. Em razão de diversas semelhanças entre $\boldsymbol{R}$. microplus e $\boldsymbol{R}$. australis, distinguir essas duas espécies torna-se uma tarefa árdua, o que explica as mudanças de classificação dessas espécies nas últimas décadas. $O$ reaparecimento da espécie $\boldsymbol{R}$. australis surge com novas pesquisas, resultado de uma melhor caracterização dessas prováveis espécies cripticas. Evidências baseadas em análises das características morfológicas, na ausência de co-especificidade, em marcadores de microssatélites, no DNA ribossomal mitocondrial $12 S$ e $16 S$, assim como no genoma mitocondrial, suportam a reclassificação de R. microplus como duas espécies distintas. Nesse sentido, populações de R. microplus da Austrália, Camboja, Nova Caledônia, Bornéo, Filipinas, Nova Guiné, Indonésia e Taiti foram recentemente renomeadas como $\boldsymbol{R}$. australis. Além disso, um melhor entendimento sobre a especiação e localização dessas duas espécies pode trazer avanços importantes para melhorar as estratégias de controle desses carrapatos.

Palavras-chave: Rhipicephalus, Boophilus, microplus, australis, taxonomia.

\section{INTRODUCTION}

Records of ticks date back to approximately 2,000 years, when they were considered anus-less animals by Pliny, the Elder (A.D. 23-79) (HILLYARD, 1996). Later, reverend Dr. Thomas Moufet (A.D. 1553-1604) noted that Ricinus means "filled with

\footnotetext{
Institute of Biotechnology and Genetic Engineering, University of Agriculture, 25130, Peshawar, Khyber Pakhtunkhwa, Pakistan. E-mail: uop_ali@yahoo.com. Corresponding author.

"Escola de Enfermagem de Ribeirão Preto, Universidade de São Paulo (USP), Ribeirão Preto, SP, Brasil.

IIICentro de Biotecnologia, Universidade Federal do Rio Grande do Sul (UFRGS), Porto Alegre, RS, Brasil.

Iv Faculdade de Veterinária, Universidade Federal do Rio Grande do Sul (UFRGS), Porto Alegre, RS, Brasil.

VInstituto Nacional de Ciência e Tecnologia em Entomologia Molecular, Universidade Federal do Rio Grande do Sul (UFRGS), Porto Alegre, RS, Brasil. 
food abundantly and yet there is no passage for any excrement" (BOWMAN \& SAUER, 2004). To answer the question from "where the first ticks were evolved?" DOBSON \& BARKER (1999) suggested that ticks evolved in the part of the supercontinent Gondwana that became Australia, in the early Devonian era, around 390 Mya ago. Contrarily, KLOMPEN et al. (2000) suggested that the hard ticks evolved 120 Mya later, after Australia became relatively isolated.

Ticks are hematophagous acarines mainly distributed in two major families, Ixodidae (hard tick) and Argasidae (soft tick) (BLACK \& PIESMAN, 1994), while only one tick species is present in the Nuttalliellidae family (GUGLIELMONE et al., 2010). Argasid ticks feed fast, but take in small volumes of blood in each meal, contrasting with Ixodid ticks, which have a longer-feeding process and ingest large amounts of blood. Ixodid ticks are unique among ectoparasites due to their long host attachment period (SAUER et al., 2000) and are divided into metastriate and prostriate ticks. Metastriate ticks include Rhipicephalus genera, characterized by relatively short mouthparts and secretion of copious amounts of cement or glue responsible for the firm attachment to its host. Prostriate ticks include the Ixodes genera, with longer and barbed mouthparts that are responsible for attachment to the host (FRANCISCHETTI et al., 2009).

Studies demonstrated differences of specific Rhipicephalus (Boophilus) spp. life cycle in different ecological zones, where varying degrees of climatic conditions affect each phase of the tick life cycle (LEGG, 1930; LONDT \& ARTHUR, 1975) and changes in these factors can difficult precise establishing of the life cycles of $\boldsymbol{R}$. microplus and R. australis.

In recent years, Boophilus spp. was reassigned to the genus Rhipicephalus (MURRELL \& BARKER, 2003). Since, based on molecular and morphological studies, some Rhipicephalus species were found to be more closely associated to $\boldsymbol{R}$. (Boophilus) species in comparison to Rhipicephalus species (MURRELL et al., 2000). Substantial morphological and molecular data have produced important evidence supporting the genus Rhipicephalus as paraphyletic to the genus Boophilus (MURRELL \& BARKER, 2003; BARKER \& MURRELL, 2004). To avoid misunderstanding and disbelief among researchers concerning name changes, Boophilus was retained as a subgeneric epithet, and Boophilus microplus became Rhipicephalus (Boophilus) microplus (GUGLIELMONE et al., 2010) or Rhipicephalus microplus.
The controversy about the classification of $\boldsymbol{R}$. australis and $\boldsymbol{R}$. microplus started in 1899, when the morphological description of Rhipicephalus australis moved this tick from the group of rhipicephalines species (FULLER, 1899). However, differences in morphological features, reproductive parameters, and genetic constitution between $\boldsymbol{R}$. microplus specimens collected in America and Africa and individuals collected in Australia provide sufficient evidences to reclassify $\boldsymbol{R}$. australis and $\boldsymbol{R}$. microplus as different species (LABRUNA et al., 2009; ESTRADA-PEÑA et al., 2012). Based on such evidence, we reviewed the data supporting the current taxonomic position of $\boldsymbol{R}$. microplus and $\boldsymbol{R}$. australis as distinct species.

\section{Current taxonomy}

\section{Morphological differences}

R. microplus, earlier named Haemaphysalis micropla Canestrini, 1888, was not precisely distinguished from $\boldsymbol{R}$. australis when this species was identified by Fuller (FULLER, 1899). However, SALMON \& STILES (1901) classified $R$. australis as a distinct species, while NEUMANN (1901) regarded $\boldsymbol{R}$. australis as a subspecies of $\boldsymbol{R}$. microplus. Several studies initially supported the conspecificity between these two species (BEDFORD, 1932; ROBERTS, 1965). Overall differences in specimens collected in Australia, America, and Africa are allegedly strong enough to support $\boldsymbol{R}$. australis as a distinct species (MINNING, 1934). Contrarily, UILENBERG (1962) concluded that these morphological variations did not validate the notion that $\boldsymbol{R}$. australis is a distinct species; therefore the author synonymized it under the name B. microplus. Similarly, for LONDT \& ARTHUR (1975) the morphological variation observed between Australian and South African R. microplus do not afford to maintain these two tick populations as distinct species. Contrarily, recent studies suggest that both female and male adults of $\boldsymbol{R}$. australis, besides this species' clearly smaller larva, differ from $\boldsymbol{R}$. microplus by a combination of other morphological characters (ESTRADA-PEÑA et al., 2012).

Despite the features closely shared by $\boldsymbol{R}$. australis and $\boldsymbol{R}$. microplus, a clear set of morphological differences persists. Larvae of $\boldsymbol{R}$. australis described as $\boldsymbol{B}$. microplus using specimens collected in Australia are smaller, with a narrow dorsal scutum than $\boldsymbol{R}$. microplus (CLIFFORD et al., 1961; ESTRADA-PEÑA et al., 2012). Adult $\boldsymbol{R}$. australis can be recognized by ventro-medial spurs in male palpal segments, and the copious, plumose, pale white setae on the female dorsum. Variability in other features like 
adanal and coxal shields among different populations often lead to incorrect classifications. R. australis possess abundant longer and pale dorsal setae, and the median alloscutal setae are arranged in clusters of 4 to 6 rows. However, this feature may be lost in engorged females. R. microplus dorsal setae are smaller and slim, and medial alloscutal setae are compose by clusters of 2 to 3 rows (WALKER et al., 2003). As compared to $\boldsymbol{R}$. microplus, the medial scutal setae in $\boldsymbol{R}$. australis female are longer. The setae behind the eyes are visible in $\boldsymbol{R}$. australis female but unapparent $\boldsymbol{R}$. microplus female. The spur in the ventral surface of $\boldsymbol{R}$. australis male is absent in $\boldsymbol{R}$. microplus male. Finally, in $\boldsymbol{R}$. microplus males possess numerous setae on the lateral margins of the ventral surface of the capitulum, which are smaller in $\boldsymbol{R}$. australis (WALKER et al., 2003; ESTRADA-PEÑA et al., 2012).

\section{Genetic differences}

Crosses mating trials

Cross mating studies are a useful tool in the differentiation of tick species. For example, $\boldsymbol{R}$. annulatus and $\boldsymbol{R}$. microplus appear to be closely related within the subgenus Boophilus, as compared to other $\boldsymbol{R}$. (Boophilus) species (BEATI \& KEIRANS, 2001). R. microplus and $\boldsymbol{R}$. annulatus cross-breeding has revealed that these two species lack conspecificity (GRAHAM et al., 1972; THOMPSON et al., 1981; DAVEY et al., 1983). A boundary in distributions of $\boldsymbol{R}$. microplus and $\boldsymbol{R}$. annulatus along the TexasMexico border suggests that these species reproduced without cross-breeding (LOHMEYER et al., 2011).

In the same way, genetic differences among $\boldsymbol{R}$. microplus strains found at specific biogeographical and ecological areas led taxonomists to consider boophilid ticks from America/Africa as different species against those from Australia. The first evidence supporting the lack of genetic conspecificity between African and Australian $\boldsymbol{R}$. microplus was provided by SPICKETT \& MALAN (1978), regarding these species as 'diverging taxa' under speciation process with recent history as distinct populations. Conversely, GUGLIELMONE et al., (2003) concluded that $\boldsymbol{R}$. microplus from South Africa and Australia should be considered as distinct species. Crossbreeding of Australian and Argentinean or Mozambican population of boophilid ticks has led to infertile animals, differently of Argentinean and Mozambican population crosses, that resulted in fertile offspring. These observations support the conclusion that tick population from Mozambique and Argentina represent a single species, while tick from
Australia is possibly a distinct species (LABRUNA et al., 2009). Furthermore, mating experiments between $\boldsymbol{R}$. microplus from South Africa and $\boldsymbol{R}$. australis from Australia produced infertile offspring (SPICKETT \& MALAN, 1978), which suggests reproductive isolation between these two species.

\section{Differences based on mitochondrial genome}

In addition to morphological observations, mitochondrial $12 \mathrm{~S}$ and $16 \mathrm{~S}$ ribosomal DNA (rDNA) has been considered a promising tool to determine phylogenetic relationships among various tick species (MANGOLD et al., 1998; BEATI \& KEIRANS, 2001; LABRUNA et al., 2009; ESTRADA-PEÑA et al., 2012; McCOOKE et al., 2015). Indeed, phylogenetic analysis based on rDNA also supports the lack of conspecificity among ticks (ESTRADA-PEÑA et al., 2012). In this way, rDNA phylogenies using sequences from a number of Australian populations lend strength to suggestion that two species is classified under the name $\boldsymbol{R}$. microplus. Besides the absence of consistent data on specimens and the few number of populations employed for the molecular and cross-breeding by LABRUNA et al. (2009), the authors believe that the available information is sufficient to support the taxonomic separation of $\boldsymbol{R}$. australis and $\boldsymbol{R}$. microplus.

As discussed above, the phylogenetic relationships among $\boldsymbol{R}$. (Boophilus) species were mostly carried out based on evolutionary relationships, relying on partial rDNA sequences (MURRELL et al., 2000, 2001, 2003; BEATI \& KEIRANS, 2001; LABRUNA et al., 2009; ESTRADA-PEÑA et al., 2012). Molecular analysis (BEATI \& KEIRANS, 2001) has confirmed the sister-species relationship between $\boldsymbol{R}$. annulatus and $\boldsymbol{R}$. microplus, as previously suggested based on morphology (FELDMANMUHSAM \& SHECHTER, 1970). Phylogenetic evidence (MURRELL et al., 2001) about the genus Rhipicephalus also supports monophyly of the Boophilus clade; however, this evidence did not solve the relationships among $\boldsymbol{R}$. (Boophilus) species. Moreover, the ' $\boldsymbol{R}$. microplus' specimens used in that work were from Australia (R. australis), and did not include $\boldsymbol{R}$. microplus s.s. Recent studies based on a wide geographic sampling range of $\boldsymbol{R}$. microplus also support monophyly of the subgenus Rhipicephalus (Boophilus), thus the reinstatement of $\boldsymbol{R}$. australis (LABRUNA et al., 2009; ESTRADA-PEÑA et al., 2012). Intriguingly, R. microplus strains collected in India and Nepal show high divergence from American and African $\boldsymbol{R}$. microplus strains (LABRUNA et al., 2009). However, the phylogenetic placement of 
Indian and Nepalese $\boldsymbol{R}$. microplus strains was not resolved, though Indian $\boldsymbol{R}$. microplus clustered with $\boldsymbol{R}$. annulatus in a $16 \mathrm{~S}$ rRNA analysis (LABRUNA et al., 2009).

Mitochondrial genomes were investigated in tick phylogenetic relationships, and have been proved useful in solving tick lineages (BURGER et al., 2012, 2013, 2014a,b; WILLIAMS-NEWKIRK et al., 2015; McCOOKE et al., 2015). To date, a few mitochondrial genomes of rhipicephaline ticks have been sequenced, and include $R$. sanguineus (BLACK \& ROEHRDANZ, 1998), R. simus (Xu et al., 2014) and 13 gene fragments of $\boldsymbol{R}$. australis mitochondrial genome (CAMPBELL \& BARKER, 1999). Whole and incomplete mitochondrial genomes of $R$. annulatus, $R$. australis, $R$. kohlsi, $\boldsymbol{R}$. geigyi, and $\boldsymbol{R}$. microplus strains from Brazil, Texas (USA) Cambodia and China were recently sequenced (BURGER et al., 2013; McCOOKE et al., 2015). Mitochondrial, cox1 and 16S rRNA phylogenetic analyses showed a species complex of $\boldsymbol{R}$. annulatus, $\boldsymbol{R}$. australis, and two clades of $\boldsymbol{R}$. microplus. Morphologically related China and India $\boldsymbol{R}$. microplus population were found closed to $\boldsymbol{R}$. annulatus than other specimens of $\boldsymbol{R}$. microplus from Asia, South America, and Africa. Furthermore, cox 1 and 16S rRNA nucleotide sequences afforded to resolve the phylogenetic relationships within the $\boldsymbol{R}$. microplus complex more successfully, as compared to $12 \mathrm{~S}$ rRNA or the nuclear marker ITS2 (CAMPBELL \& BARKER, 1999; LEMPEREUR et al., 2010; BURGER et al., 2013).

Microsatellite markers

The genetic differences between $\boldsymbol{R}$. microplus populations from the TEQA (tick eradication quarantine area) USA, Mexico, and Puerto Rico were first investigated using isozymes over three decades ago (SATTLER et al., 1986). Analysis of fifteen selected polymorphic loci demonstrated heterozygosity to arthropods and high genetic similarity among various strains, suggesting an undifferentiated gene pool in $\boldsymbol{R}$. microplus populations prevalent in North America. Later, microsatellite polymorphism was investigated in tick populations from Argentina, Australia, India, Mozambique, and New Caledonia. Tissues of homologous and heterologous crosses were analyzed, and allele numbers and sizes were determined for each locus. The clustering analysis of microsatellite alleles from $\boldsymbol{R}$. microplus offspring crosses revealed that Australian homologous and heterologous crosses had lower similarity, in comparison to homologous and heterologous crosses between Mozambique and Argentinian strains (LABRUNA et al., 2009).

In New Caledonia, R. microplus has been found in close contact with sympatric hosts, on cattle and on a new host, the rusa deer (Cervus timorensis), divided into two differentiated genetic pools. In North America, the white-tailed deer (Odocoileus virginianus) and the red deer are also well-studied examples that illustrate this pattern of new sympatric hosts. This phenomenon may have occurred across the globe, in areas where this tick has established some degree of interaction with distinct host species in sympatry with livestock (KOFFI et al., 2006a; DE MEEUS et al., 2010; ARAYA-ANCHETTA et al., 2015). Using eight microsatellite loci, low genetic structure was found in specimens of $\boldsymbol{R}$. australis in New Caledonia (KOFFI et al., 2006b). Analyses using 11 microsatellite markers revealed that the genetic differences between Australian $\boldsymbol{R}$. australis populations endemic in Queensland and New South Wale are not significant; however, the observed diversity among strains within each location proposes limitations to local gene flow (CUTULLÉ et al., 2009). A significant and small genetic structure was detected in ticks that infest rusa deer or domestic cattle (De MEEUS et al., 2010), which suggests that this sympatric adaptation resulted in host-specific populations. Recently, microsatellite markers were successfully used to detect genetic variation among $\boldsymbol{R}$. microplus strains in Texas (BUSCH et al., 2014). Undifferentiated tick collections were analyzed using 11 repeat loci, and it was not possible to identify any genetic divergence between $\boldsymbol{R}$. microplus sampled from white-tailed deer and specimens collected from cattle, even when the ticks were obtained from the same pastures (BUSCH et al., 2014). When parasitized by cattle ticks, these wild ungulates pose a major obstacle to eradication programs, since the difficulty to treat these animals with acaricides (POUND et al., 2010).

\section{Differences in Bm86 gene sequences}

Characterization employing an intron and DNA short tandem repeats (STRs) from Bm86 gene of Latin America and Australia R. microplus populations revealed significant differences within the Bm86 coding region between ticks from these regions (De La FUENTE et al., 2000). The intron sequence dissipated in the phylogenetic analysis, showing that individuals of the same strain do indeed vary. Moreover, polymorphism analysis at STR suggests differences within and between populations of $\boldsymbol{R}$. microplus, which supports the 
molecular level of existence between $\boldsymbol{R}$. microplus populations (De La FUENTE et al., 2000).

Ecological niche

Field data on regional distribution are necessary to clarify the actual distribution and the evolution of $\boldsymbol{R}$. microplus and $\boldsymbol{R}$. australis. It has been hypothesized that $\boldsymbol{R}$. microplus originated in South and Southeast Asia (HOOGSTRAAL, 1985), later spreading to Madagascar and Southern Africa. Data required to shed more light on how and when $R$. microplus spread to Americas is scarce (LABRUNA et al., 2009), although it is reasonable that the tick was brought attached on livestock imported from India or Africa 4-5 centuries ago (BARRÉ \& UILENBERG, 2010). Since $\boldsymbol{R}$. microplus is specific to ungulates, the transportation of European cattle (Bos taurus) has spread it throughout the tropical and subtropical belt. As compared to tropical Bovidae, European bovines are almost incapable of eliciting efficient immune responses to $\boldsymbol{R}$. microplus infestations (FRISCH, 1999). Other factors that may have constrained the geographical distribution of $\boldsymbol{R}$. microplus include climate variables and competition with other tick species (ESTRADA-PEÑA et al., 2006; CHEVILLON et al., 2013). Furthermore, it was suggested that $\boldsymbol{R}$. australis was introduced in Australia and New Caledonia on livestock in 1829 (ANGUS, 1996), and 1942 (VERGES, 1944; DE MEEÛS et al., 2010), respectively. Today, $\boldsymbol{R}$. australis is prevalent in Australia, Cambodia, Philippines, Indonesia, New Caledonia, Borneo, Malaysia, New Guinea and Tahiti (LABRUNA et al., 2009; ESTRADA-PENA et al., 2012; LOW et al., 2015). $R$. microplus is endemic between parallels $32^{\circ} \mathrm{N}$ and $32^{\circ} \mathrm{S}$, where the major cattle breeding countries are, including newly reported ecological preferences in West Africa (MADDER et al., 2007; ESTRADA-PEÑA et al., 2006; LEGER et al., 2013). In addition, $\boldsymbol{R}$. microplus and $\boldsymbol{R}$. australis coexist in southeastern Asian countries (LOW et al., 2015). However, climate changes may further modify the potential geographical distribution of these parasites.

Implications in control methods

Economically, ticks are among the most potentially harmful parasites worldwide (PIESMAN \& EISEN, 2008; GRISI et al., 2014). During infestation, ticks may transmit numerous pathogenic bacterial, viral, and protozoan organisms to the host (HAJDUSEK et al., 2013). The combination of the tick vectoring ability and the overall undermining of the host's health caused by blood uptake leads to high losses in livestock and pet industries (WILLADSEN, 2004). R. microplus was introduced in the New
World by tick-infested cattle brought by explorers and colonists (HOOGSTRAAL, 1985). Estimated losses caused by these ectoparasites during the first decade of the $19^{\text {th }}$ century reached about US\$63 billion (MOHLER, 1906). Therefore, due to the huge economic impact caused by $\boldsymbol{R}$. microplus, the United States started a national campaign to eradicate Boophilus in 1906, and by 1943 this program was declared complete (GRAHAM \& HOURRIGAN, 1977). Considering Brazil alone, which has the largest industrial cattle herd in the world; potential losses caused by $\boldsymbol{R}$. microplus are estimated at US\$3.24 billion yearly (GRISI et al., 2014). Tick control is a daunting challenge, because current control methods based on synthetic acaricides are becoming increasingly inefficient (RECK et al., 2014).

Effective new control strategies demand a precisely parasitological epidemiology, because these strategies are affected by the presence of $\boldsymbol{R}$. microplus in a given geographical area. Vaccination experiments demonstrated different degrees of susceptibility for Bm86-based vaccines by $\boldsymbol{R}$. microplus populations, suggesting the existence of genetically distinct strains of $\boldsymbol{R}$. microplus (COBON et al., 1995; GARCIA-GARCIA et al., 2000). The Bm86 vaccine developed from an Australian ' $\boldsymbol{R}$. microplus' strain showed very low efficacy when used in Latin America, as compared to Bm95, a Bm86 homologue from the Argentinian R. microplus strain, which showed higher vaccinal efficacy in this region (GARCIA-GARCIA et al., 2000). Likewise, a Bm86 formulation from Cuban R. microplus showed higher protection levels in America, when compared with Bm86 from Australian ' $R$. microplus' (De La FUENTE et al., 2007). Consequently, it is important to clearly describe vaccination data regarding the tick strain analyzed, due to the observed speciesspecificity of protection levels. Moreover, risk areas for tick-borne disease also need re-analysis, given the potential differences in vector capability by these two tick species.

\section{CONCLUSION}

The triumph of taxonomy at species level is an open tool for continuous and exciting discoveries. Better understanding of $\boldsymbol{R}$. microplus and $\boldsymbol{R}$. australis taxonomic structure is pivotal for control measures against these ticks. Further studies on population genetic of Rhipicephalus (Boophilus) spp. will more thoroughly explain the interactions among these parasites, the pathogens they vector, and their hosts. In addition, such studies will provide more in-depth information 
about tick movements, disease dispersal, and designing anti-tick control programs. Genetic variance studies among Rhipicephalus (Boophilus) spp. will better elucidate the identification of cryptic species. Mixed infestation, when the parasites are in close contact with sympatric alternative hosts (like deer, for instance) is a major hurdle for eradication programs. However, more detailed information about genetic differentiation and genetic population structure could provide tools to improve control strategies. As demonstrated in recent years, the lack of effective protection induced by the Bm86 vaccine can be partly explained considering the presence of different $\boldsymbol{R}$. microplus strains. These failed vaccine experiments can be explained if $\boldsymbol{R}$. microplus is considered not a single, but two distinct species. Although $\boldsymbol{R}$. australis is very similar to $\boldsymbol{R}$. microplus, both the larvae and adults of each species have a clear set of species-specific characters. In conclusion, reported results confirm that two distinct species of ticks were named $\boldsymbol{R}$. microplus.

\section{ACKNOWLEDGMENT}

This work was supported by grants from Higher Education Commission, Pakistan Science Foundation (Pakistan), Conselho Nacional de Desenvolvimento Científico e Tecnológico (CNPq), and Coordenação de Aperfeiçoamento de Pessoal de Nível Superior (CAPES). We would like to thanks Dr. Carlos Termignoni for critical reading of this review.

\section{REFERENCES}

ALI, A. et al. Probing the functional role of tick metalloproteases. Physiological Entomology, v.40, p.177, 188, 2015. Available from: $<$ http://onlinelibrary.wiley.com/doi/10.1111/phen.12104/abstract $>$. Accessed: Sept. 27, 2015. doi: 10.1111/phen.12104.

ANGUS, B.M. The history of the cattle tick Boophilus microplus in Australia and achievements in its control. International Journal for Parasitology, v.26, p.1341-1355, 1996. Available from: <http:// www.sciencedirect.com/science/article/pii/S0020751996001129>. Accessed: Jun. 05, 2015. doi: 10.1016/s0020-7519(96)00112-9.

ARAYA-ANCHETTA, A. et al. Thirty years of tick population genetics: A comprehensive review. Infection Genetics and Evolution, v.29, p.164-179, 2015. Available from: $<$ http://www. sciencedirect.com/science/article/pii/S1567134814004110>. Accessed: Oct. 01, 2015. doi: 10.1016/j.meegid.2014.11.008

BARKER, S.C.; MURRELL, A. Systematics and evolution of ticks with a list of valid genus and species names. Parasitology, v.129, p.S15-S36, 2004. Available from: <http://www.ncbi.nlm.nih. gov/pubmed/15938503>. Accessed: Feb. 07, 2015. doi: 10.1017/ S0031182004005207.

BARRÉ, N.; UILENBERG, G. Spread of parasites transported with their hosts: case study of two species of cattle tick. Revue scientifique et technique (International Office of Epizootics), v.29, p.149-160, 2010.
BEATI, L.; KEIRANS, J.E. Analysis of the systematic relationships among ticks of the genera Rhipicephalus and Boophilus (Acari: Ixodidae) based on mitochondrial $12 \mathrm{~S}$ ribosomal DNA gene sequences and morphological characters. Journal of Parasitology, v.87, p.32-48, 2001. Available from: <http://www.ncbi.nlm. nih.gov/pubmed/11227901>. Accessed: Mar. 12, 2015. doi: 10.1645/0022-3395(2001)087[0032:AOTSRA]2.0.CO;2.

BEDFORD, G.A.H. A synoptic check-list and host-list of the ectoparasites found on South African Mammalia, Aves, and Reptilia. Journal of Veterinary Science and Animal Industry, v.7, p.69-110, 1932.

BLACK, W.C.; PIESMAN, J. Phylogeny of hard- and soft-tick taxa (Acari: Ixodidae) based on mitochondrial 16S rDNA sequences. Proceedings of the National Academy of Sciences USA, v.91, p.10034-10038, 1994.

BLACK, W.C.; ROEHRDANZ, R.L. Mitochondrial gene order is not conserved in arthropods: prostriate and metastriate tick mitochondrial genomes. Molecular Biology and Evolution, v.15, p.1772-1785, 1998.

BOWMAN, A.S.; SAUER J.R. Tick salivary glands: function, physiology and future. Parasitology, v.129, p.S67-S81, 2004. Available from: <http://www.ncbi.nlm.nih.gov/pubmed/15938505>. Accessed: Apr. 2, 2015. doi: 10.1017/S0031182004006468.

BURGER, T.D. et al. Molecular phylogeny of soft ticks (Ixodida: Argasidae) inferred from mitochondrial genome and nuclear rRNA gene sequences. Ticks and Tick-Borne Diseases, v.5, p.195-207, 2014b. Available from: <http://www.sciencedirect.com/science/ article/pii/S1877959X13001234>. Accessed: Jul. 14, 2015. doi: 10.1016/j.ttbdis.2013.10.009.

BURGER, T.D. et al. Phylogenetic analysis of mitochondrial genome sequences indicates that the cattle tick, Rhipicephalus (Boophilus) microplus, contains a cryptic species. Molecular Phylogenetics and Evolution, v.76, p.241-253, 2014a. Available from: $<$ http://www.sciencedirect.com/science/article/ pii/S1055790314001171>. Accessed: May 14, 2015. doi: 10.1016/j.ympev.2014.03.017.

BURGER, T.D. et al. Phylogenetic analysis of the mitochondrial genomes and nuclear rRNA genes of ticks reveals a deep phylogenetic structure within the genus Haemaphysalis, and further elucidates the polyphyly of the genus Amblyomma with respect to Amblyomma sphenodonti and Amblyomma elaphense. Ticks and Tick-Borne Diseases, v.4, p.265-274, 2013. Available from: <http:// www.sciencedirect.com/science/article/pii/S1877959X13000344>. Accessed: Apr. 06, 2015. doi: 10.1016/j.ttbdis.2013.02.002.

BURGER, T.D. et al. Phylogenetic analysis of ticks (Acari: Ixodidae) using mitochondrial genomes and nuclear rRNA genes indicates that the genus Amblyomma is polyphyletic. Molecular Phylogenetic and Evolution, v.64, p.45-55, 2012. Available from: < http://www.sciencedirect.com/science/article/pii/ S1055790312001091>. Accessed: Sept. 04, 2015. doi: 10.1016/j. ympev.2012.03.004.

BUSCH, J.D. et al. Widespread movement of invasive cattle fever ticks (Rhipicephalus microplus) in southern Texas and shared local infestations on cattle and deer. Parasites \& Vectors, v.7, p.188, 2014. Available from: $<$ http://parasitesandvectors.biomedcentral. com/>. Accessed: May 17, 2015. doi: 10.1186/1756-3305-7-188. 
CAMPBELL, N.J.H.; BARKER, S.C. The novel mitochondrial gene arrangement of the cattle tick, Boophilus microplus: five fold tandem repetition of a coding region. Molecular Biology and Evolution, v.16, p.732-740, 1999.

CHEVILLON, C. et al. Understanding the genetic, demographical and/or ecological processes at play in invasions: lessons from the southern cattle tick Rhipicephalus microplus (Acari: Ixodidae). Experimental and Applied Acarology, v.59, p.203-218. 2013. Available from: <http://link.springer.com/article/10.1007\% 2Fs 10493-012-9602-5>. Accessed: Jun. 14, 2015. doi: 10.1007/ s1 0493-012-9602-5.

CLIFFORD, C.M. et al. The larval Ixodid ticks of the eastern United States (Acarina: Ixodidae). Miscellaneous publications of the Entomological Society of America, v.2, p.213-237, 1961.

COBON, G. et al. Vaccination against Boophilus microplus: the Australian field experience. In: FUENTE, J. de la (Ed.). Recombinant vaccines for the control of cattle tick. Havana: Elfos Scintiae, 1995. p.163-176.

CUMMING, G.S.; VUUREN D.V.P. Will climate change affect ectoparasite species ranges. Global Ecology and Biogeography, v.15, p.486-497, 2006. Available from: <http://onlinelibrary.wiley. com/doi/10.1111/j.1466-822X.2006.00241.x/abstract>. Accessed: May 15, 2015. doi: 10.1111/j.1466-822 X.2006.00241.x.

CUTULLÉ, C. et al. Population structure of Australian isolates of the cattle tick Rhipicephalus (Boophilus) microplus. Veterinary Parasitology, v.161, p.283-291, 2009. Available from: <http:// www.sciencedirect.com/science/article/pii/S0304401709000326>. Accessed: Sept. 25, 2015. doi: 10.1016/j.vetpar.2009.01.005.

DAVEY, R.B. et al. Longevity and mating behavior in males and parthenogenesis in females in hybridized Boophilus ticks (Acari: Ixodidae). Journal of Medical Entomology, v.20, p.614-617, 1983.

DE LA FUENTE, J. et al. A ten-year review of commercial vaccine performance for control of tick infestations on cattle. Animal Health Research Reviews, v.8, p.23-38, 2007. Available from: $<$ http://www.ncbi.nlm.nih.gov/pubmed/17692140>. Accessed: May 02, 2015. doi: 10.10 17/S1466252307001193.

DE LA FUENTE, J. et al. Molecular analysis of Boophilus spp. (Acari: Ixodidae) tick strains. Veterinary Parasitology, v.92, p.209-222, 2000. Available from: <http://www.ncbi.nlm.nih.gov/ pubmed/10962158>. Accessed: May 12, 2015. doi: 10.1016/ S0304-4017(00)00308-3.

DE MEEÛS, T. et al. Swift sympatric adaptation of a species of cattle tick to a new deer host in New Caledonia. Infection, Genetics and Evolution, v.10, p.976-983, 2010. Available from: <http:// www.sciencedirect.com/science/article/pii/S1567134810001693>. Accessed: Apr. 16, 2015. doi: 10.1016/j.meegid.2010.06.005.

DOBSON, S.J.; BARKER, S.C. Phylogeny of the hard ticks (Ixodidae) inferred from 18S rRNA indicates that the genus Aponomma is paraphyletic. Molecular Phylogenetics and Evolution, v.11, p.288-295, 1999. Available from: <http://www. ncbi.nlm.nih.gov/pubmed/10191073>. Accessed: Jun. 28, 2015. doi: $10.1006 /$ mpev.1998.0565.

ESTRADA-PEÑA, A. et al. Reinstatement of Rhipicephalus (Boophilus) australis (Acari: Ixodidae) with redescription of the adult and larval stages. Journal of Medical Entomology, v.49, n.4, p.794-802, 2012. Available from: <http://www.ncbi. nlm.nih.gov/pubmed/22897039>. Accessed: Jan. 13, 2015. doi: 10.1603/ME11223.

ESTRADA-PEÑA, A. et al. The known distribution and ecological preferences of the tick subgenus Boophilus (Acari: Ixodidae) in Africa and Latin America. Experimental and Applied Acarology, v.38, p.219-235, 2006.

FELDMAN-MUHSAM, B.; SHECHTER, R. Some notes on the genus Boophilus (Ixodidae) with special reference to species found in Israel. Journal of Medical Entomology, v.7, p.677-686, 1970. Available from: <http://www.ncbi.nlm.nih.gov/pubmed/5501234>. Accessed: Sept. 13, 2014. doi: 10.1093/jmedent/7.6.677.

FRANCISCHETTI, I.M. et al. The role of saliva in tick feeding. Frontier Bioscience (Landmark Ed), v.14, p.2051-2088, 2009.

FRISCH, J. Towards a permanent solution for controlling cattle tick. International Journal for Parasitology, v.29, p.57-71, 1999. Available from: $<$ http://www.sciencedirect.com/science/article/pii/ S0020751998001775>. Accessed: Sept. 12, 2014. doi: 10.1016/ S0020-7519(98)00177-5.

FULLER, C. Notes on the Queensland cattle tick and its relationship to the red water tick and the blue tick of Cape Colony (South Africa). Queensland Agricultural Journal, v.4, p.389-394, 1899.

GARCIA-GARCIA, J.C. et al. Sequence variations in the Boophilus microplus Bm86 locus and implications for immunoprotection in cattle vaccinated with this antigen. Experimental and Applied Acarology, v.23, p.883-895, 1999.

GRAHAM, O.H. et al. Cross-mating experiments with Boophilus annulatus and B. microplus (Acarina: Ixodidae). Journal of Medical Entomology, v.9, p.531-537, 1972. Available from: $<\mathrm{http}$ ://jme.oxfordjournals.org/content/9/6/531.long $>$. Accessed: Jan. 15, 2014. doi: 10.1093/jmedent/9.6.531

GRAHAM, O.H.; HOURRIGAN, J.L. Eradication programs for the arthropod parasites of livestock. Journal of Medical Entomology, v.13, p.629-658, 1977. Available from: $<$ http://www. ncbi.nlm.nih.gov/pubmed/328882>. Accessed: May 12, 2014. doi: $10.1093 /$ jmedent/13.6.629.

GRISI, L. et al. Reassessment of the potential economic impact of cattle parasites in Brazil. Revista Brasileira de Parasitologia Veterinaria, v.23, p.150-156, 2014. Available from: <http://www. ncbi.nlm.nih.gov/pubmed/25054492>. Accessed: May 25, 2015. doi: 10.1590/S1984-29612014042.

GUGLIELMONE, A. et al. Ticks (Acari: Ixodidae) of the Neotropical Zoogeographic Region. The Netherlands: Atalanta Houten, 2003. (Special Publication, International Consortium on Ticks and Tick-borne Diseases)

GUGLIELMONE, A.A. et al. The Argasidae, Ixodidae and Nuttalliellidae (Acari: Ixodidae) of the world: a list of valid species names. Zootaxa, v.2528, p.1-28, 2010. Available from: $<$ http://www.mapress.com/zootaxa/2010/f/z02528p028f.pdf>. Accessed: Jan. 23, 2014.

HAJDUSEK, O. et al. Interaction of the tick immune system with transmitted pathogens. Frontiers in Cellular and Infection Microbiology, v.3, p.26, 2013. Available from: <http://www.ncbi. 
nlm.nih.gov/pubmed/23875177>. Accessed: Mar. 23, 2014. doi $10.3389 /$ fcimb. 2013.00026

HILLYARD, P.D. Ticks of North-West Europe: keys and notes for identification of the species. Shrewsbury: Linnean Society of London and the Estuarine and Coastal Sciences Association by Field Studies Council, 1996. 178p.

HOOGSTRAAL, H. Argasid and nuttalliellid ticks as parasites and vectors. Advances in Parasitology, v.24, p.135-238, 1985. Available from: $<$ http://www.ncbi.nlm.nih.gov/pubmed/3904345> Accessed: May 23, 2014. doi: 10.1016/S0065-308X(08)60563-1.

KLOMPEN, J.S.H. et al. Systematics and biogeography of hard ticks, a total evidence approach. Cladistics, v.16, p.79-102, 2000 Available from: $<$ http://www.sciencedirect.com/science/article/pii/ S0748300799901263>. Accessed: Nov. 19, 2014. doi: 10.1006/ clad.1999.0126.

KOFFI, B.B. et al. Characterization of polymorphic microsatellite loci within a young Boophilus microplus metapopulation. Molecular Ecology, v.6 p.502-504, Notes 2006b. Available from: $<$ http://agritrop.cirad.fr/533705/>. Accessed: May 12, 2015. doi: 10.1111/j.1471-8286.2006.01295.x

KOFFI, B.B. et al. Founder effects, inbreeding and effective size in the Southern cattle tick: the effect of transmission dynamics and implications for pest management. Molecular Ecology, v.15, p.4603-4611, 2006a. Available from: <http://onlinelibrary.wiley. com/doi/10.1111/j.1365-294X.2006.03098.x/abstract>. Accessed: Jan. 16, 2015. doi: 10.1111/j.1365-294X.2006.03098.x.

LABRUNA, M.B. et al. Allopatric speciation in ticks: genetic and reproductive divergence between geographic strains of Rhipicephalus (Boophilus) microplus. BMC Evolutionary Biology, v.9, p.4 6-58, 2009. Available from: <http://www. biomedcentral.com/1471-2148/9/46>. Accessed: Jan. 12, 2014

LEGER, E. et al. Changing distributions of ticks. causes and consequences. Experimental and Applied Acarology, v.59, p.219-244, 2013. Available from: <http://link.springer.com/article $/ 10.1007 \% 2 F s 10493-012-9615-0>$. Accessed: Dec. 23, 2014. doi $10.1007 / \mathrm{s} 10493-012-9615-0$.

LEGG, J. Some observations on the life history of the cattle tick (Boophilus australis). Proceeding of Royal Society Queensland, v.41, p.121-32, 1930 .

LEMPEREUR, L. et al. Development and validation of a PCRRFLP test to identify African Rhipicephalus (Boophilus) ticks. Acta Tropica, v.114, p.55-58, 2010. Available from: $<$ http://www. sciencedirect.com/science/article/pii/S0001706X10000070>. Accessed: Sept. 13, 2014. doi: 10.1016/j.actatropica.2010.01.004.

LOHMEYER, K.H. et al. Distribution of Rhipicephalus (Boophilus) microplus and Rhipicephalus (Boophilus) annulatus (Acari: Ixodidae) infestations detected in the United States along the Texas/Mexico Border. Journal of Medical Entomology, v.48, p.770-774, 2011. Available from: <http://jme. oxfordjournals.org/content/48/4/770.long>. Accessed: Oct 16, 2015. doi: 10.1603/ME10209.

LONDT, J.G.H.; ARTHUR, D.R. The structure and parasitic life cycle of Boophilus microplus (Canestrini, 1888) in South Africa (Acarina: Ixodidae). Journal of the Entomological Society of South Africa, v. 38 p.321-340, 1975.
LOW, V. et al. Molecular characterization of the tick Rhipicephalus microplus in Malaysia: new insights into the cryptic diversity and distinct genetic assemblages throughout the world. Parasites \& Vectors, v.8, p.341, 2015. Available from: <http://www.ncbi.nlm. nih.gov/pmc/articles/PMC4482097/>. Accessed: May 16, 2015. doi: 10.1186/s13071-015-0956-5.

MADDER, M. et al. Rhipicephalus (Boophilus) microplus ticks found in West Africa. Experimental and Applied Acarology, v.43, p.233-234, 2007. Available from: < http://link.springer.com/ article /10.1007\%2Fs10493-007-9110-1>. Accessed: May 27, 2014. doi: 10.1007/s10493-007-9110-1.

MANGOLD, J.J. et al. Mitochondrial 16S rDNA sequences and phylogenetic relationships of species of Rhipicephalus and other tick genera among Metastriata (Acari: Ixodidae). Parasitology Research, v.84, p.478-484, 1998. Available from: <http://www. ncbi.nlm.nih.gov/pubmed/9660138>. Accessed: Jan. 12, 2014. doi: $10.1007 / \mathrm{s} 004360050433$.

McCOOKE, J.K. et al. The mitochondrial genome of a Texas outbreak strain of the cattle tick, Rhipicephalus (Boophilus) microplus, derived from whole genome sequencing Pacific Biosciences and Illumina reads. Gene, v.571, p.135-141, 2015. Available from: $<$ http://www.ncbi.nlm.nih.gov/pubmed/26117172>. Accessed: Oct. 29, 2015. doi: 10.1016/j.gene. 2015.06. 060.

MEEUS, T. et al. Swift sympatric adaptation of a species of cattle tick to a new deer host in New Caledonia. Infection Genetics and Evolution, v.10, p.976-983, 2010. Available from: <http:// www.sciencedirect.com/science/article/pii/S1567134810001693>. Accessed: Jan. 19, 2015. doi: 10.1016/j.meegid.2010.06.005.

MINNING, W. Beitrage zur Systematik und Morphologie der Zeckengattung Boophilus curtice. Z. Zeitschrift für Parasitenkunde, v.7, p.1-43, 1934.

MOHLER, J.R. Texas or tick fever and its prevention. Farm Bulletin of United States Department of Agriculture, v.238, p.1-44, 1906.

MURRELL, A. et al. A total-evidence phylogeny of ticks provides insights into the evolution of life cycles and biogeography. Molecular Phylogenetics and Evolution, v.21, p.244-258, 2001. Available from: <http://www.sciencedirect.com/science/article/ pii/S1055790301910188>. Accessed: Jul. 23, 2014. doi: 10.10 06/mpev.2001.1018.

MURRELL, A. et al. Phylogenetic analyses of the rhipicephaline ticks indicate that the genus Rhipicephalus is paraphyletic. Molecular Phylogenetics and Evolution, v.16, p.1-7, 2000. Available from: $<$ http://www.sciencedirect.com/science/article/pii/ S1055790300907620>. Accessed: Sept. 27, 2014. doi: 10.1006/ mpev.2000.0762.

MURRELL, A. et al. The value of idiosyncratic markers and changes to conserved tRNA sequences from the mitochondrial genome of hard ticks (Acari: Ixodida: Ixodidae) for phylogenetic inference. Systematic Biology, v.52, p.296-310, 2003. Available from: $<\mathrm{http}: /$ sysbio.oxfordournals.org/content/52/3/296.long>. Accessed: Jan. 12, 2015. doi: 10.1080/10635150390196957.

MURRELL, A.; BARKER, S.C. Synonymy of Boophilus curtice, 1891 with Rhipicephalus koch, 1844 (Acari: Ixodidae). Systematic Parasitology, v.56, p.169-172, 2003. Available from: $<$ http://www.ncbi.nlm.nih.gov/pubmed/14707501>. Accessed: May 12, 2014. doi: 10.1023/B:SYPA.0000003802.36517.a0. 
NEUMANN, L.G. Revision de la famille des Ixodides Mem. Bulletin de la Société zoologique de France, v.14, p.249-372, 1901.

OLWOCH J.M. et al. Climate change and the genus Rhipicephalus (Acari: Ixodidae) in Africa. Onderstepoort Journal of Veterinary Research, v.74, p.45-72, 2007. Available from: <http://www.ncbi. nlm.nih.gov/pubmed/17708153>. Accessed: Sept. 21, 2014. doi: 10.4102/ojvr.v74i1.139.

PIESMAN, J.; EISEN, L. Prevention of tick-borne diseases Annual Reviews of Entomology, v.53, p.323-343, 2008. Available from: <http://www.annualreviews.org $>$. Accessed: Dec. 12, 2014. doi: 10.1146/annurev.ento.53.103106.093429.

POUND, J.M. et al. Evidence for role of white-tailed deer (Artiodactyla: Cervidae) in epizootiology of cattle ticks and southern cattle ticks (Acari: Ixodidae) in reinfestations along the Texas/Mexico border in south Texas: a review and update. Journal of Economic Entomology, v.103, p.211-218, 2010. Available from: <http://jee.oxfordjournals.org/>. Accessed: Sept. 27, 2015. doi: 10.1603/EC09359.

RECK, J. et al. First report of fluazuron resistance in Rhipicephalus microplus: a field tick population resistant to six classes of acaricides. Veterinary Parasitology, v.20, p.128-136, 2014. Available from: $<$ http://www.ncbi.nlm.nih.gov/pubmed/24560364>. Accessed: May 23, 2015. doi: 10.1016/j.vetpar.2014.01.012.

ROBERTS, F.H.S. The taxonomic status of the species of the genera Rhipicephalus koch and Boophilus curtice (Acarina: Ixodidae) occurring in Australia. Australian Journal of Zoology, v.13, p.491-523, 1965. Available from: <http://www.publish. csiro.au/paper/ZO9650491.htm>. Accessed: Dec. 05, 2014. doi: 10.1071/ZO9650491.

SALMON, D.E.; STILES, C.W. The cattle ticks (Ixodoidea) of the United States. In: ANNUAL REPORT OF THE UNITED STATE, 17, 1901, Washington: Department of Agriculture, Bureau of Animal Industry, 1901. p.380-491.

SATTLER, P.W. et al. Genetic similarity and variability between natural populations and laboratory colonies of North American Boophilus (Acari: Ixodidae). Journal of Parasitology, v.72, p.95-100, 1986. Available from: <http://www.ncbi.nlm.nih.gov/ pubmed/3712179>. Accessed: Dec. 12, 2014. doi: 10.2307/3281799.
SAUER, J.R. et al. Salivary glands in ixodid ticks: control and mechanism of secretion. Journal of Insect Physiology, v.46, p.10691078, 2000. Available from: <http://www.sciencedirect. com/science/article/pii/S0022191099002103>. Accessed: Dec. 23, 2014. doi: 10.1016/S0022-1910(99)00210-3.

SPICKETT, A.M.; MALAN, J.R. Genetic incompatibility between Boophilus decoloratus (Koch, 1844) and Boophilus microplus (Canestrini, 1888) and hybrid sterility of Australian and South African Boophilus microplus (Acarina: Ixodidae). Onderstepoort Journal of Veterinary Research, v.45, p.149-153, 1978.

THOMPSON, G.D. et al. Hybrid sterility in cattle ticks. Experientia, v.37, p.127-128, 1981. Available from: <http://www. ncbi.nlm.nih.gov/pubmed/571591>. Accessed: Dec. 21, 2014. doi: 10.1007/BF01963186.

TONNESEN, M.H. et al. Displacement of Boophilus decoloratus by Boophilus microplus in the Soutpansberg region, Limpopo province, South Africa. Experimental and Applied Acarology, v.32, p.199-208, 2004. Available from: <http://www.ncbi.nlm. nih.gov/pubmed/15139085>. Accessed: Jan. 15, 2015. doi: 10.1023/B:APPA.0000021789.44411.b5

UILENBERG, G. Boophilus (Uroboophilus) fallax Minning, 1934 synonyme de Boophilus microplus (Canestrini, 1887) (Ixodidae). Revue d'elevage et de Medecine Veterinaire des Pays Tropicaux, v.15, p.387-398,1962.

VERGES J. Les tiques du Betail. Methodes d'eradication. Noumea: Imprimeries reunies, 1944. 72p.

WALKER, A.R. et al. Ticks of domestic animals in Africa: a guide to identification of species. Bioscience Reports, Edinburgh, 203. 221p.

WILlADSEN, P. Anti-tick vaccines. Parasitology, v.129, p.S367-S387, 2004. Available from: <http://www.ncbi.nlm.nih. gov/pubmed/15938519>. Accessed: Dec. 07, 2014. doi: 10.1017/ S003118200300 4657 .

XU, Z. et al. Complete mitochondrial genome of Rhipicephalus simus. Mitochondrial DNA: The Journal of DNA Mapping, Sequencing, and Analysis. p 888-889. Accessed from: $<$ http:// www.tandfonline.com/>. Accessed: Feb. 10, 2016. doi: 10.3109/19401736. 2014.919490. 